\title{
PERAN PERGURUAN TINGGI DALAM MENDUKUNG KINERJA DPRD KOTA PEMATANGSIANTAR
}

\section{THE ROLE OF UNIVERSITIES IN SUPPORTING PERFORMANCE OF THE PEMATANGSIANTAR CITY DPRD}

\author{
Apriani Sijabat ${ }^{1 *}$, Herna Febrianty Sianipar ${ }^{2}$, Theresia Monika Siahaan ${ }^{3}$, \\ Christa Voni Roulina Sinaga ${ }^{4}$, Ropinus Sidabutar ${ }^{3}$, Susy Alestari Sibagariang ${ }^{5}$, \\ Mungkap Siahaan ${ }^{6}$ \\ ${ }^{1}$ Phyisics Education, Universitas HKBP Nommensen Pematangsiantar \\ ${ }^{2}$ Aquatic Resource Management Study Program, Universitas HKBP Nommensen Pematangsiantar \\ ${ }^{3}$ Mathematics Education, Universitas HKBP Nommensen Pematangsiantar \\ ${ }^{4}$ Mathematics, Universitas HKBP Nommensen Pematangsiantar \\ ${ }^{5}$ Economic Education, Universitas HKBP Nommensen Pematangsiantar \\ ${ }^{6}$ English Education, Universitas HKBP Nommensen Pematangsiantar \\ *Email: aprianisijabat@gmail.com \\ (Diterima 02-09-2021; Disetujui 24-09-2021)
}

\begin{abstract}
ABSTRAK
HKBP Nommensen Universitas Pematangsiantar melakukan pengabdian masyarakat di kantor DPRD Kota Pematangsiantar, dimana pengabdian ini bertujuan untuk mendukung kinerja DPRD Kota Pematangsiantar khususnya dalam menanggulangi permasalahan sampah sesuai dengan peraturan daerah yang berlaku. Pelayanan ini mendapat respon yang baik dan diapresiasi oleh Ketua Komisi 3 DPRD Pematangsiantar. Tingkat kepuasan peserta PKM juga mencapai 80\%. Hal ini menunjukkan bahwa kegiatan pengabdian ini berdampak positif terhadap kesejahteraan masyarakat Kota Pemangsiantar. Diharapkan melalui kegiatan ini terjalin kerjasama antara pihak universitas dengan pemerintah daerah yang bertujuan untuk mensejahterakan masyarakat.
\end{abstract}

Kata kunci: kinerja, DPRD, program

\section{ABSTRACT}

HKBP Nommensen Pematangsiantar University conducts community service at the Pematngsiantar City DPRD office, where this service aims to support the performance of the Pematangsiantar City DPRD, especially in tackling the waste problem in accordance with applicable local regulations. This service received a good response and was appreciated by the chairman of Commission 3 of the Pematangsiantar DPRD. The level of satisfaction of PKM participants also reached $80 \%$. This shows that this service activity has a positive impact on the welfare of the people of Pemangsiantar City. It is hoped that through this activity there will be cooperation between the university and the local government aimed at the welfare of the community.

Keywords: performance, DPRD, program

\section{PENDAHULUAN}

Kota Pematangsiantar (sering disingkat Siantar saja) adalah salah satu kota di Provinsi Sumatera Utara, dan kota terbesar kedua di provinsi tersebut setelah Medan. Karena letak Pematangsiantar yang strategis, ia dilintasi oleh Jalan Raya Lintas Sumatera. Kota ini memiliki luas wilayah 79,97 km2 dan berpenduduk sebanyak 240.787 jiwa (2000). Kota Pematangsiantar yang hanya berjarak $128 \mathrm{~km}$ dari Medan dan $52 \mathrm{~km}$ dari Parapat sering menjadi kota perlintasan bagi wisatawan yang hendak ke Danau Toba. 
Peran Perguruan Tinggi Dalam Mendukung Kinerja DPRD Kota Pematangsiantar

Apriani Sijabat, Herna Febrianty Sianipar, Theresia Monika Siahaan, Christa Voni Roulina Sinaga, Ropinus Sidabutar, Susy Alestari Sibagariang, Mungkap Siahaan

Sebagai kota penunjang pariwisata di daerah sekitarnya, kota ini memiliki 8 hotel berbintang, 10 hotel melati dan 268 restoran. Di kota ini masih banyak terdapat sepeda motor BSA model lama sebagai becak bermesin yang menimbulkan bunyi yang keras. Kota ini pernah menerima Piala Adipura pada tahun 1993 atas kebersihan dan kelestarian lingkungan kotanya. Sementara itu, karena ketertiban pengaturan lalu-lintasnya, kota ini pun meraih penghargaan Piala Wahana Tata Nugraha pada tahun 1996. Wakil Presiden Republik Indonesia yang ke-3 Adam Malik, lahir di kota ini pada 22 Juli 1917. Sektor industri yang menjadi tulang punggung perekonomian kota yang terletak di tengah-tengah Kabupaten Simalungun ini adalah industri besar dan sedang.

Kampus Universitas HKBP Nommensen Pematangsiantar (UHKBPNP) berada di Jl. Sangnaualuh No.4 Pematangsiantar, Kec. Siantar Timur, Sumatera Utara. Lokasi kampus ini sangat strategis, karena arus transportasi lancar dan merupakan jalan penghubung antar kabupaten yang satu dengan kabupaten yang lain, dekat dengan perkotaan, sehingga keberadaan kampus ini dengan mudah dapat dijangkau dari seluruh penjuru masyarakat. Disamping itu, secara geografis kota Pematangsiantar terletak pada garis $2^{\circ} 53^{\prime} 20^{\prime \prime}-3^{\circ} 01^{\prime}$

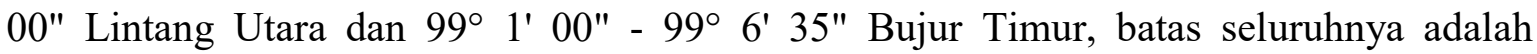
wilayah Kab. Simalungun dengan jarak tempuh $128 \mathrm{~km}$ dari Medan dan $50 \mathrm{~km}$ dari Parapat. Kota Pematangsiantar tergolong daerah tropis dan daerah datar, beriklim sedang dengan suhu maksimum rata-rata 30,20 0C dan suhu minimum rata-rata 20,8 oC pada tahun 2018. Kota Pematangsiantar memiliki luas wilayah 79,97 km2 atau 011\% dari luar Provinsi Sumatera Utara (Sumut) yang berpenduduk 282.101 jiwa (RLLDP kota Pematangsiantar, 2018). Kampus UHKBPNP memiliki luas $140.000 \mathrm{~m} 2$, tanah dan bangunan milik sendiri yang diselenggarakan oleh Yayasan Universitas HKBP Nommensen (YUHN) dengan Akta Notaris Badan Hukum Penyelenggaraan dan Perubahannya N o . 03 tanggal 3 Mei 2017 dan teregistrasi oleh Menteri Hukum dan HAM No.: AU-AH.01.06-004965 tanggal 8 Mei 2017. UHKBPNP mengelola 3 Fakultas, yaitu: (1) Fakultas Keguruan dan Ilmu Pendidikan (FKIP); (2) Fakultas Matematika dan Ilmu Pengetahuan Alam (FMIPA); dan (3) Fakultas Teknik Pengelolaan Sumber Daya Perairan (FTPSDP). FKIP menyelenggarakan 10 Program Studi Sarjana, yaitu: (1) Pendidikan Bahasa Indonesia; (2) Pendidikan Bahasa Inggris; (3) Pendidikan Bahasa Jerman; (4) Pendidikan Ekonomi; (5) Pendidikan Kewarganegaraan; (6) Pendidikan Matematika; (7) Pendidikan Kimia; (8) Pendidikan Biologi, (9) Pendidikan Fisika, dan (10). Pendidikan Guru Sekolah Dasar (PGSD). FMIPA mengelola Program Studi Matematika dan FTPSDP mengelola Program Studi Teknik Mesin dan Sumber Daya Perairan. 
Menurut peraturan daerah Kota Pematangsiantar nomor 11 tahun 2012 tentang pengelolaan sampah khususnya Pasal 6 tentang Tugas Pemerintahan Daerah sebagaimana dimaksud dalam Pasal 5, terdiri atas :

a. Menumbuh kembangkan dan meningkatkan kesadaran masyarakat dalam pengelolaan sampah;

b. melakukan penelitian, pengembangan teknologi pengurangan, dan penanganan sampah;

c. memfasilitasi, mengembangkan, dan melaksanakan upaya pengurangan, penanganan dan pemanfaatan sampah;

d. melaksanakan pengelolaan sampah dan memfasilitasi penyediaan prasarana dan sarana pengelolaan sampah;

e. mendorong dan memfasilitasi pengembangan manfaat hasil pengelolaan sampah;

f. memfasilitasi penerapan teknologi spesifik lokal yang berkembang pada masyarakat setempat untuk mengurangi dan menangani sampah; dan

g. melakukan koordinasi antar lembaga pemerintahan daerah, masyarakat, dan dunia usaha agar terdapat keterpaduan dalam pengelolaan sampah.

Berdasarkan peraturan daerah tersebut maka pihak Universitas HKBP Nommensen Pematangsiantar, khususnya Program Studi Pendidikan Fisika, turut berkontribusi dalam mendukung kinerja DPRD kota Pematangsiantar dalam menanggulangi beberapa permasalahan sampah di kota Pematangsiantar.

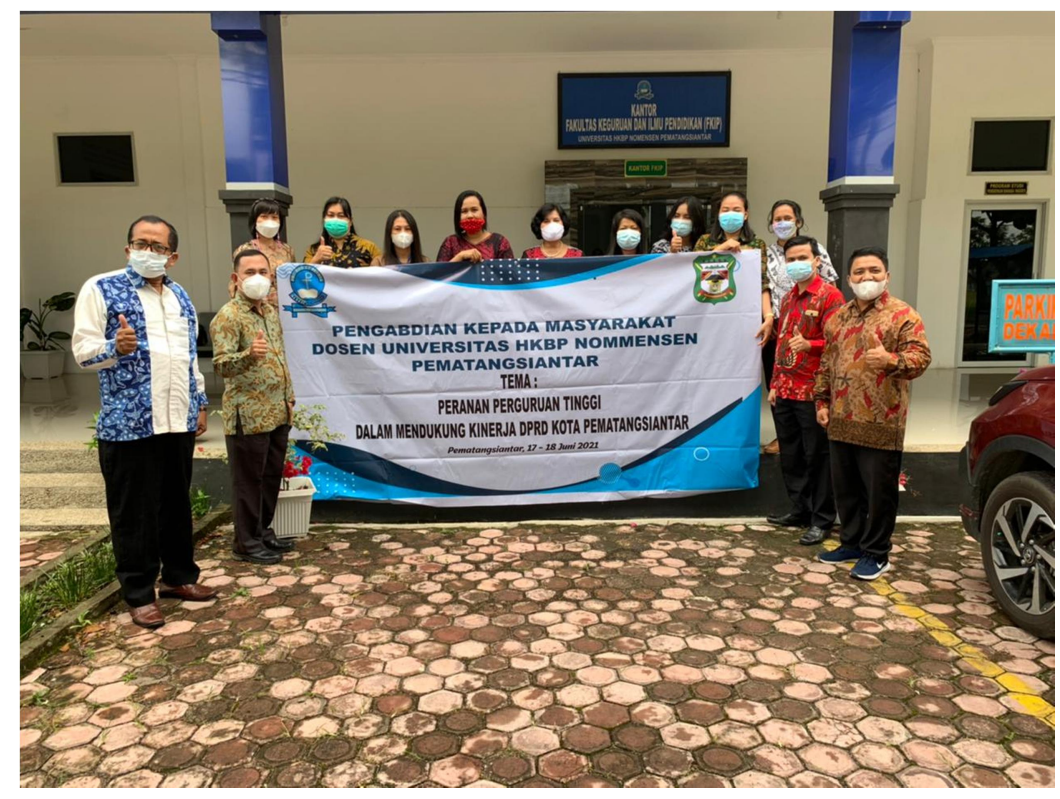

Gambar1. Foto Tim Pengabdi 
Peran Perguruan Tinggi Dalam Mendukung Kinerja DPRD Kota Pematangsiantar

Apriani Sijabat, Herna Febrianty Sianipar, Theresia Monika Siahaan, Christa Voni Roulina Sinaga, Ropinus Sidabutar, Susy Alestari Sibagariang, Mungkap Siahaan

\section{BAHAN DAN METODE}

Kegiatan pengabdian ini diawali dengan penjajakan lokasi dan pengurusan perizinan untuk melakukan pengabdian kepada masyarakat di kantor DPRD Kota Pematangsiantar sekaligus menyepakati waktu pelaksanaan. Adapun sasaran pada kegiatan ini adalah anggota dewan DPRD Pematangsiantar yang membidangi bidang pendidikan. Dalam teknis pelaksanaan, tim pengabdian masyarakat akan mengkonfirmasi kembali anggota kelompok yang akan mengikuti sosialisasi peran Program Studi Pendidikan Fisika yang mendukung kinerja DPRD kota Pematangsiantar. Kegiatan PKM ini dilaksanakan pada bulan Juni 2021 dan dilaksanakan di kantor DPRD Kota Pematangsiantar. Metode pelaksanaan program PKM ini meliputi dua hal yaitu sebagai berikut:

1. Metode Sosialisasi

Metode sosialisasi merupakan salah satu metode yang akan dikembangkan dalam program PKM. Metode sosialisasi ini sangat penting pada anggota kelompok mitra untuk menambah pengetahuan sehingga terjadi perubahan kognitif. Artinya pola pikir yang dirubah terlebih dahulu untuk memudahkan proses kegiatan PKM selajutnya.

2. Metode Angket

Setelah melakukan sosialisasi kepada anggota dewan DPRD Kota Pematangsiantar maka tim pengabdi memberikan angket kepada peserta PKM untuk mendapatkan tingkat kepuasan terhadap pengadian yang telah dilakukan. Angket ini kemudian nanti akan dianalisis untuk memperoleh data yang diperlukan.

\section{HASIL DAN PEMBAHASAN}

Kegiatan dilaksanakan selama dua hari yang dimulai dari tanggal 17-18 Juni 2021 yang berlokasi di kantor DPRD Kota Pematangsiantar. Kegiatan secara resmi dibuka oleh Bapak Denny Siregar selaku Ketua Komisi 3 DPRD Kota Pematangsiantar. Hari pertama kegiatan merupakan sosialisasi tentang peranan Program Studi Pendidikan Fisika dalam mendukung kinerja DPRD Kota Pematangsiantar.

Penerimaan yang dilakukan oleh anggota dewan cukup baik dan sangat terbuka bahkan antusias. Hal ini ditunjukkan dari diskusi antara anggota dewan dengan tim pengabdi untuk kesejateraan masyarakat Kota Pematangsiantar. 


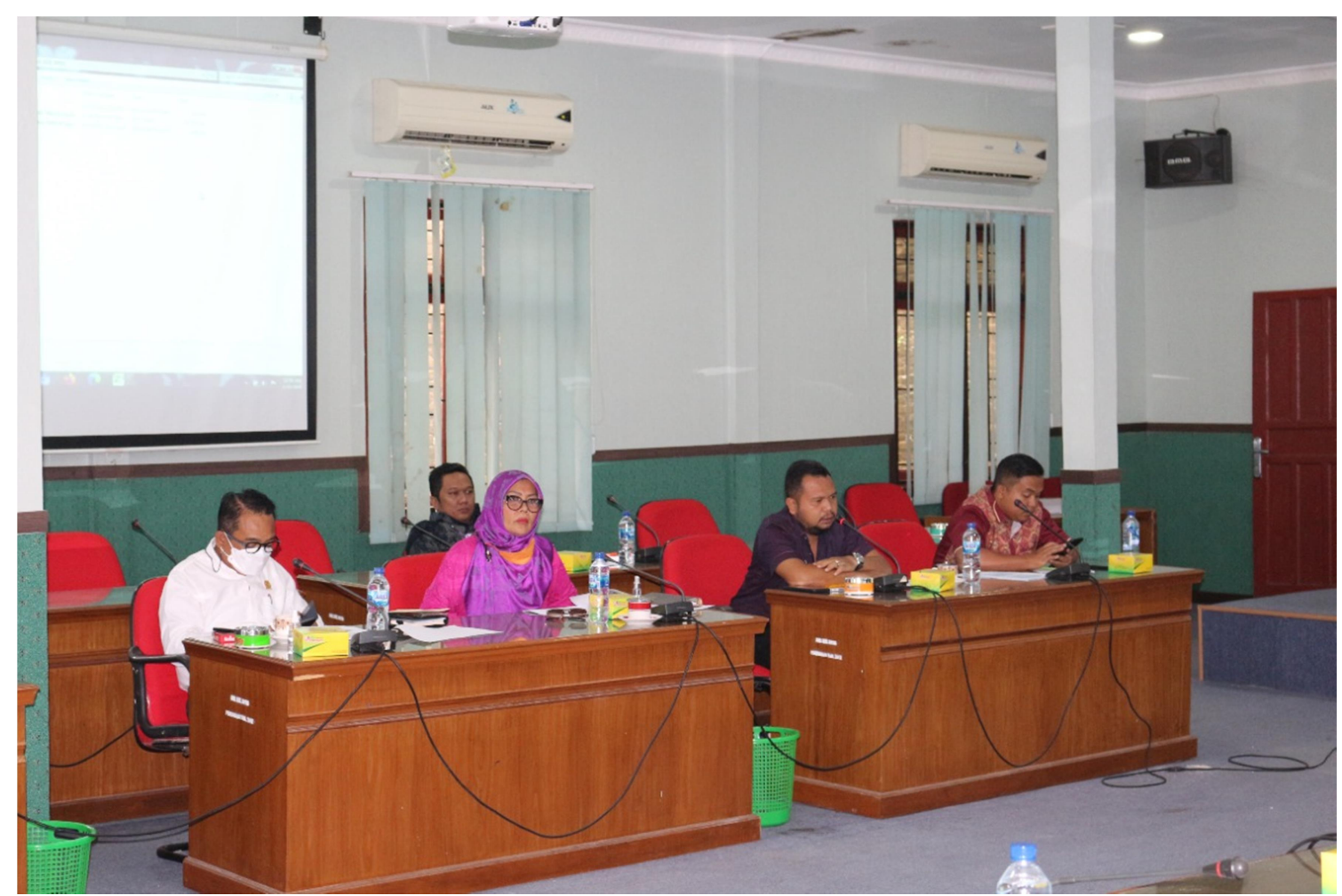

Gambar 2. Foto Anggota Dewan yang mengikuti sosialisasi

Adapun materi yang disampaikan oleh tim pengabdi kepada anggota dewan adalah bahwa Program Studi Pendidikan Fisika yang berada di FKIP UHKBPNP Pematangsiantar berperan serta dalam mendukung kinerja DPRD Kota Pematangsiantar, dimana Prodi Pendidikan Fisika turut berpartisipasi dalam hal mengagulangi permasalahan sampah yang ada di kota Pematangsiantar, diantaranya:

1. Limbah Ban Bekas jadi, Sol Sepatu, Karpet.

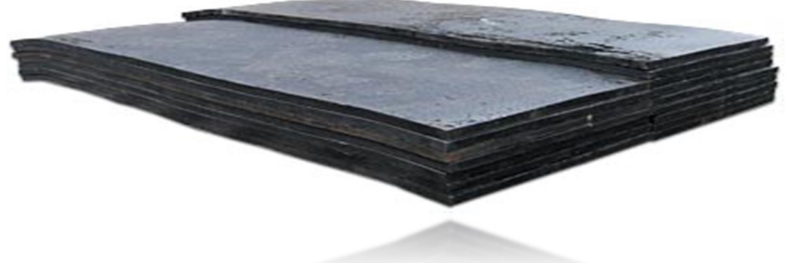

2. Pemanfaatan sampah dan limbah tani sebagai briket (arang)

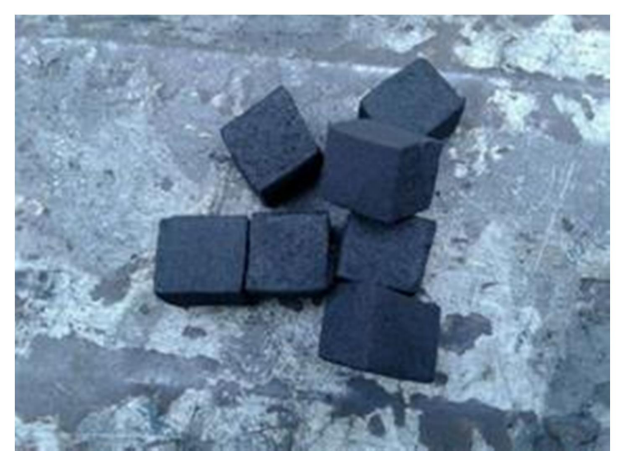


3. Pemanfaatan limbah serat sabut kelapa sebagai papan partikel
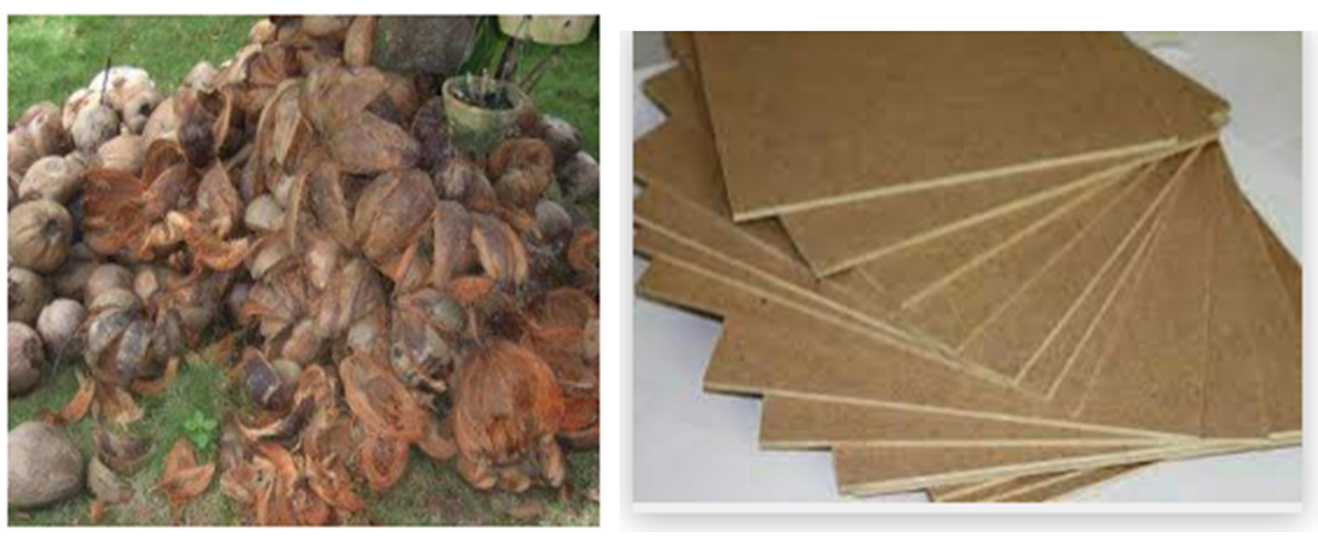

4. Pemanfaatan limbah plastik menjadi komposit

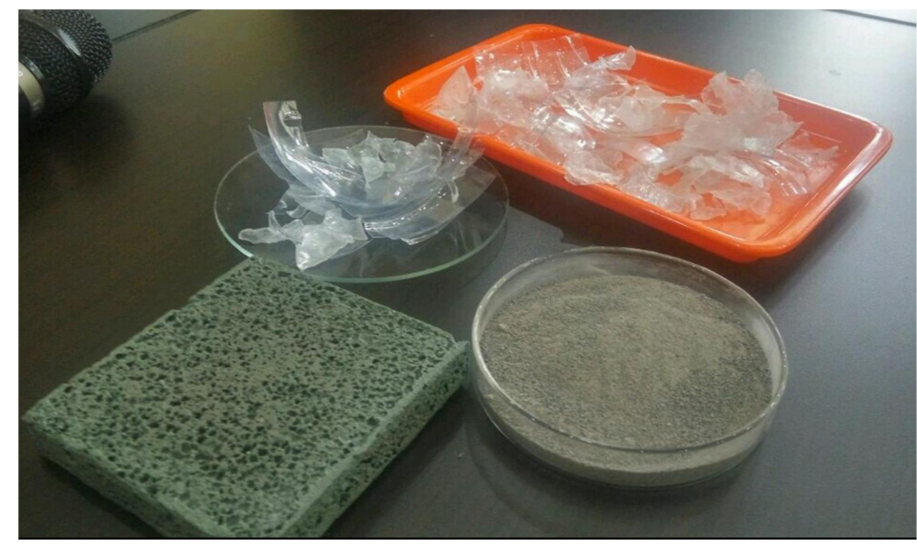

5. Limbah Tongkol jagung dan eceng gondok dijadikan papan partikel sebagai bahan souvenir dan perabotan

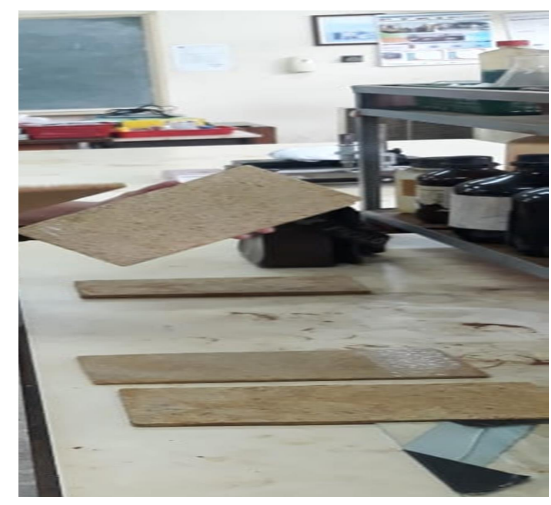

Diharapkan dengan saling bekerjasama antara pihak perguruan tinggi khususnya Program Studi Pendidikan Fisika dapat menghasilkan produk dari sampah yang dapat diolah menjadi barang yang lebih berguna serta dapat membantu masyarakat bahkan dapat membuka peluang usaha mikro di kota Pematangsiantar. 
Kegiatan pengabdian yang dilakukan oleh tim pengabdi dari UHKBPNP di kantor DPRD Kota Pematangsiantar diapresiasi oleh Bapak Ketua Komisi 3, diharapkan setelah pengabdian ini dapat dijalin kerjasama yang lebih lanjut untuk mensejaterakan masyarakat kota Pematangsiantar. Anggota dewan yang hadir pada kegiatan ini ada sebanyak 10 orang dari anggota DPRD Kota Pematangsiantar. Setelah melakukan sosialisasi tentang peran Program Studi Pendidikan Fisika yang mendukung kinerja DPRD Kota Pematangsiantar maka tim pengabdi memberikan angket untuk diisi oleh anggota DPRD yang mengikuti ssosialisasi. Adapun bentuk angket yang dibagikan adalah sebagai berikut:

Tabel 1 . Angket Kepuasan Peserta

\begin{tabular}{|c|c|c|c|c|c|}
\hline No & Pernyataan & $\mathrm{SS}$ & $\mathrm{S}$ & $\mathrm{TS}$ & STS \\
\hline 1 & $\begin{array}{l}\text { Saya merasa puas dengan kegiatan pengabdian masyarakat yang } \\
\text { diselengggarakan Dosen Universitas HKBP Nommensen } \\
\text { Pematangsiantar }\end{array}$ & & & & \\
\hline 2 & $\begin{array}{l}\text { Kegiatan pengabdian masyarakat yang diselenggarakan Dosen } \\
\text { Universitas HKBP Nommensen Pematangsiantar sesuai dengan } \\
\text { harapan saya }\end{array}$ & & & & \\
\hline 3 & $\begin{array}{l}\text { Personil/ anggota yang terlibat dalam kegiatan pengabdian masyarakat } \\
\text { memberikan pelayanan sesuai dengan kebutuhan saya }\end{array}$ & & & & \\
\hline 4 & $\begin{array}{l}\text { Setiap keluhan / pertanyaan / permasalahan yang saya ajukan } \\
\text { ditindaklanjuti dengan baik oleh narasumber/ anggota yang terlibat }\end{array}$ & & & & \\
\hline 5 & $\begin{array}{l}\text { Jika kegiatan ini diselenggarakan kembali, saya bersedia untuk } \\
\text { berpartsipasi/ terlibat }\end{array}$ & & & & \\
\hline
\end{tabular}

Keterangan : $\mathrm{SS}=$ sangat setuju, $\mathrm{S}=\mathrm{Setuju}, \mathrm{TS}=$ tidak setuju, $\mathrm{STS}=$ sangat tidak setuju

Berdasarakan angket yang telah diisi oleh anggota DPRD sebagai peserta pengabdian maka hasilnya diperoleh sebagaimana terlihat pada Tabel 2.

Tabel 2. Tingkat Kepuasan Peserta Pengabdian

\begin{tabular}{|c|c|c|c|c|c|c|c|}
\hline \multirow{2}{*}{ No } & \multirow{2}{*}{ Pernyataan } & \multirow{2}{*}{$\mathrm{SS}$} & \multirow{2}{*}{$\mathrm{S}$} & \multicolumn{4}{|c|}{ Persentase $(\%)$} \\
\hline & & & & $\mathrm{SS}$ & $\mathrm{S}$ & $\mathrm{TS}$ & STS \\
\hline 1 & $\begin{array}{l}\text { Saya merasa puas dengan kegiatan pengabdian masyarakat } \\
\text { yang diselengggarakan Dosen Universitas HKBP } \\
\text { Nommensen Pematangsiantar }\end{array}$ & 8 & 2 & 80 & 20 & 0 & 0 \\
\hline 2 & $\begin{array}{l}\text { Kegiatan pengabdian masyarakat yang diselenggarakan } \\
\text { Dosen Universitas HKBP Nommensen Pematangsiantar } \\
\text { sesuai dengan harapan saya }\end{array}$ & 7 & 3 & 70 & 30 & 0 & 0 \\
\hline 3 & $\begin{array}{l}\text { Personil/ anggota yang terlibat dalam kegiatan pengabdian } \\
\text { masyarakat memberikan pelayanan sesuai dengan } \\
\text { kebutuhan saya }\end{array}$ & 8 & 2 & 80 & 20 & 0 & 0 \\
\hline 4 & $\begin{array}{l}\text { Setiap keluhan / pertanyaan / permasalahan yang saya } \\
\text { ajukan ditindaklanjuti dengan baik oleh narasumber/ } \\
\text { anggota yang terlibat }\end{array}$ & 6 & 4 & 60 & 40 & 0 & 0 \\
\hline 5 & $\begin{array}{l}\text { Jika kegiatan ini diselenggarakan kembali, saya bersedia } \\
\text { untuk berpartsipasi/ terlibat }\end{array}$ & 9 & 1 & 90 & 10 & 0 & 0 \\
\hline
\end{tabular}

Berdasarkan hasil tingkat kepuasan peserta PKM maka diperoleh bahwa peserta kegiatan PKM 80\% menyatakan sangat setuju dengan kegiatan ini dan tidak ada peserta yang menyatakan tidak setuju, bahkan sangat tidak setuju dengan kegiatan PKM yang telah 
Peran Perguruan Tinggi Dalam Mendukung Kinerja DPRD Kota Pematangsiantar

Apriani Sijabat, Herna Febrianty Sianipar, Theresia Monika Siahaan, Christa Voni Roulina Sinaga, Ropinus Sidabutar, Susy Alestari Sibagariang, Mungkap Siahaan

dilaksanakan. Hal ini menujukkan bahwa kegiatan pengabdian ini memberikan dampak yang positif bagi peserta PKM.

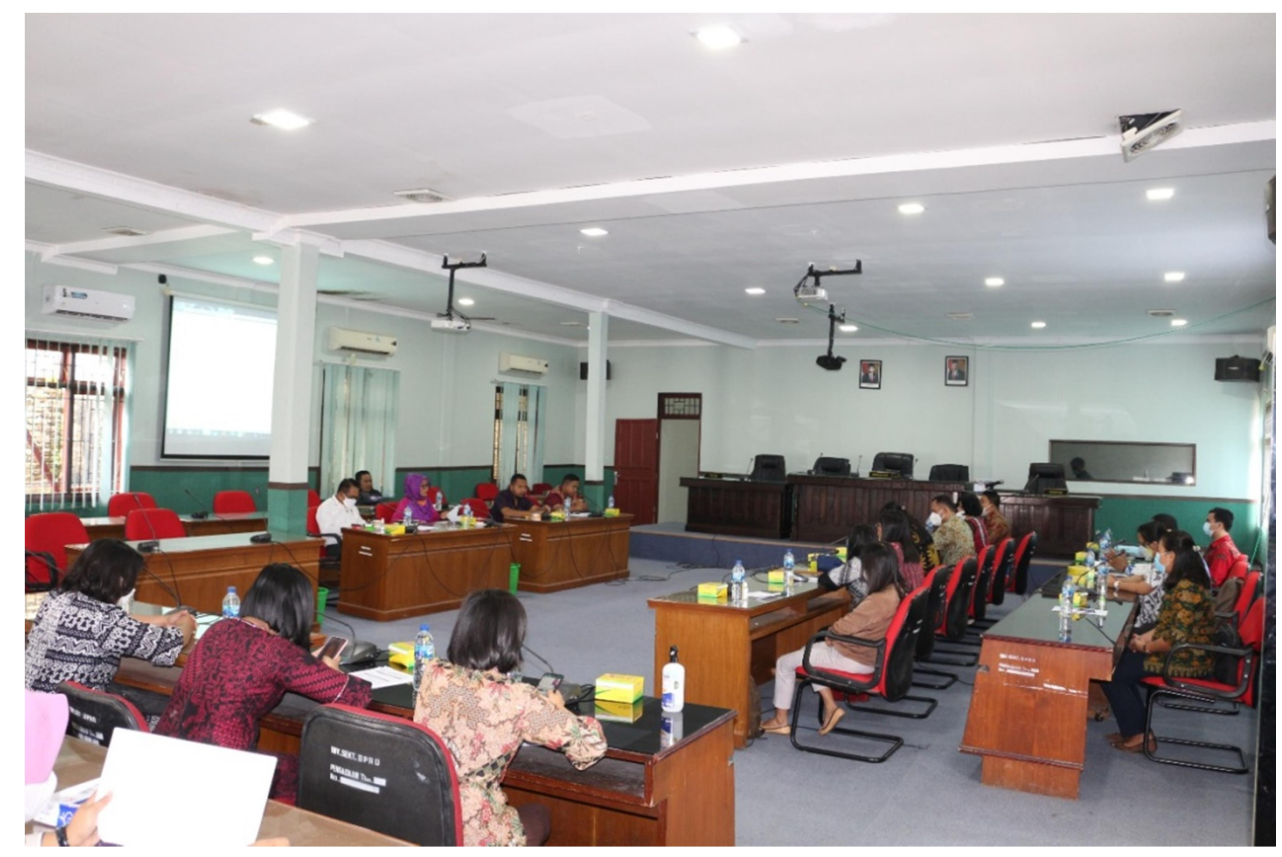

Gambar 3. Foto Kegiatan PKM di Kantor DPRD

\section{KESIMPULAN DAN SARAN}

Setelah melakukan pengabdian ini,maka tim pengabdi dapat menyimpulkan bahwa kegiatan yang dilakukan oleh tim pengabdi dari dosen Univeristas HKBP Nommensen Pematangsiantar dapat mendukung kinerja dari DPRD Kota Pematangsiantar untuk mensejahterakan masyarakat yang ada di Kota Pematangsiantar. Diharapkan ke depannya terjalin kerjasama yang baik antara pihak perguruan tinggi dengan DPRD guna kesejahteraan masyarakat. Kegiatan ini juga dapat dilakukan di daerah lain sehingga terjalin mitra yang baik antara pihak perguruan tinggi dengan lembaga pemerintahan daerah.

\section{DAFTAR PUSTAKA}

(https://berita.pematangsiantar.go.id/?page_id=69)

Millet, Jhon. The Academic Community. New York: McGraw Hill, 1962. Mondy, R. Wayne, and Robert

M. Noe. 2005. Human Resource Management. Ninth Edition. USA: Prentice Hall. Mahsun. 2006.

Manajemen Kepegawaian. Yogyakarta: Kanisius. Maryoto. Susilo. 2000. Managemen Sumber Daya Manusia, Edisi 3. Penerbit BPFE, Yogyakarta

RLLDP Kota Pematangsiantar (2018).

Website uhnp.ac.id 